\title{
Implications Neuroscience for Teaching Practice
}

\section{Fenny Fadhilaturrahmi}

fennyfadhilaturrahmi@gmail.com

\begin{abstract}
Although neuroscience studies have provided us with an increasingly detailed picture of the basis for learning and memory, very little of this information has been applied within the area of teaching practice. We suggest that a better understanding of neuroscience may offer significant advantages for educators. In this context, we have considered recent studies in the neuroscience of learning and memory, with particular emphasis on working and semantic memory, and also suggest that neuroscience research into self-referential networks may improve our understanding of the learning process. Finally, we propose that advances in understanding the neural basis for metacognition may encourage the development of new perspectives that may help us to motivate students to learn about their own learning processes.
\end{abstract}

Keywords: neuroscience, education, learning, memory, default network, metacognition

Although there has been considerable discussion about neuroscience in relation to education, 1 there appear to be very few outcomes with respect to teaching practice. 2 It is logical to assume that further progress may require cross-disciplinary integration of research from psychology, neuroscience, machine learning, and education, 3 particularly because, at present, there is no clear consensus on the nature of learning.4-6 To facilitate such cross-disciplinary discussion, the use of technical terms has been limited and the current paper uses an education-centered approach focused on learning that involves conscious processes that require goals and the associated strategies required to achieve them.7 Neuroscience studies have shown that the learning process involves both working memory (WM) and long-term memory (LTM) 8 and associated control processes in the prefrontal cortex (PFC) that select and manipulate goal-relevant information. As these PFC regions appear to play a crucial role in controlling learning processes, reference has been made specifically to both the dorsal and ventral lateral prefrontal cortices (DLPFC and VLPFC) and the anterior prefrontal cortex (APFC).

Working memory plays a critical role in the learning process because it has been shown to facilitate the formation, strengthening, and expansion of LTM.9,10 The control component of WM has been associated with the DLPFC, and this region appears to be involved in the selection, monitoring, and maintenance of goal-relevant information held temporarily in the posterior association cortex (PAC).11,12 The WM system is only capable of processing a limited subset (3-5) of items at any one time, but remains active until new information is selected.13 From an educational perspective various strategies have been used to facilitate entry of relevant material into WM by, for example, adapting instructional design and by managing cognitive load (eg, by focussing on the main points of a task and by removing distractions).14-16 However, recent findings have increased our understanding of WM with respect to flexibility in goal pursuit and learning. This work has elucidated how DLPFC control may switch from maintaining current information to permitting WM to update with new, relevant, information.17,18 Consideration of these mechanisms may help to extend thinking about the role of WM in an educational context and help us understand educational research results where WM capacity and motivation can be used to identify different student learning profiles.19

Working memory only stores information for a relatively short period, and LTM is thus essential. One type of LTM is semantic (factual/concept) memory (SM), which is both a result and a critical component of the learning process.20 Learning appears to be not only concerned with the long-term storage of specific facts, but with the formation of associations between facts (concepts), and this stored information can be referred to as a semantic framework.21 According to some authors, associations and associative processing may form the basis for thought and learning,22 and neuroscience studies may provide useful directions for 
computational modeling studies of these processes.23,24 From an educational point of view, an understanding of these mechanisms may help to support the suggested use of analogical reasoning as a means to strengthen associations between facts.25 The storage of SM involves the PAC, particularly the temporal pole,26 and the control of SM selection and retrieval has been associated with the VLPFC, which shows stronger activity when a learning task includes concepts or facts that are only distantly related.11,2729 However, association of a common object with an unusual function (eg, a shoe used as a flower pot) also activates the APFC in addition to the previously mentioned regions.30 The APFC is thought to represent the highest level within the control process hierarchy because it is activated during abstract reasoning and metacognition.31-33 Educators may benefit from an understanding of how facts and their relationships are processed by the brain, particularly when considering the use of graphical representations of concepts in the form of "concept maps" and the like.34

One area of neurophysiology research that has only had a limited impact on teaching practice is that related to the default mode of brain activity (a default network of brain regions where processing may become suspended during task-related action).35,36 This default network is thought to include brain regions involved in self-referential processing (ie, thinking about oneself or how others relate to you) and memory retrieval.37 Such a putative network is important to consider with respect to learning for two reasons. First, the common phenomenon of "mind wandering" may reduce the effectiveness of task performance and learning38 and has been posited to be associated with engagement of the default network.39 On the other hand the default network has also been associated with useful activities such as planning and autobiographical goal setting (imagining future personal experiences).37 It has been proposed that both taskrelated and default networks may contribute to achieving a particular goal.40 In summary these findings indicate that learning may involve not only the more established task-related networks, but may also require support from "internal" prospective mechanisms involving "self." "Switching" to the "default" network may, therefore, be important where students work with others in a group situation and where their estimation of self and that of others may impact on learning. 41 However the interaction between task performance and self-referential activities has yet to be established in a formal learning context.

It is clear that representations of personal brain function can be made (metacognition) 42 and that this ability plays an important role in reasoning and planning 43 and in communicating internal states to others. 44 Both the APFC and the DLPFC provide a major contribution to metacognition, and changes in APFC gray matter volume may reflect the effects of learning in individuals.33,45 Individual differences in metacognitive ability, established by neural and behavioral studies, suggest that metacognitive training should be considered (learning how to learn), and Mayer46 proposed that improving metacognition should be a primary educational objective. Although metacognitive reporting usually mirrors task performance, the two can sometimes be dissociated.45,47 Therefore, one should be vigilant with respect to the value placed on verbal or written reports relating to "self," because educational research often depends on student selfreporting. 47

Finally, the lessons learned by consideration of neural representations and control hierarchies may aid the development of individualized intelligent tutoring systems.48 Although human tutors can provide effective learning support, increasing class numbers make one-to-one tutoring much more difficult to achieve. Computer-based tutors may help to support individual student learning by selecting appropriate problems to be solved and by providing alternative solution strategies, feedback, and hints.48-50 An understanding of neuroscience and an interdisciplinary synthesis of research may lead to optimum outcomes for teaching practice.

\section{Acknowledgements}

The authors would like to thank Anggi Cecilia Safaningrum for providing useful feedback on the manuscript.

\section{Competing Interests}

Author disclose no potential conflicts of interest. 


\section{Disclosures and Ethics}

Authors disclose no competing interests to submit this paper.

\section{Funding}

Authors disclose no funding sources.

\section{References}

1. Clement ND, Lovat T. Neuroscience and education: issues and challenges for curriculum. Curriculum Inq. 2012;42(4):534-557. [Google Scholar]

2. Oliver M. Towards an understanding of neuroscience for science educators. Stud Sci Educ. 2011;47(2):211-235. [Google Scholar]

3. Meltzoff AN, Kuhl PK, Movellan J, Sejnowski TJ. Foundations for a new science of learning. Science. 2009;325(5938):284-288. [PMC free article] [PubMed] [Google Scholar]

4. Alexander PA, Schallert DL, Reynolds RE. What is learning anyway? A topographical perspective considered. Educl Psychol. 2009;44(3):176-192. [Google Scholar]

5. Graesser AC. Cognitive scientists prefer theories and testable principles with teeth. Educ Psychol. 2009;44(3):193197. [Google Scholar]

6. Säljö R. Learning, theories of learning, and units of analysis in research. Educ Psychol. 2009;44(3):202-208. [Google Scholar]

7. Miller EK, Cohen JD. An integrative theory of prefrontal cortex function. Annu Rev Neurosci. 2001;24:167-202. [PubMed] [Google Scholar]

8. Barrett LF, Tugade MM, Engle RW. Individual differences in working memory capacity and dual-process theories of the mind. Psychol Bull. 2004;130(4):553-573. [PMC free article] [PubMed] [Google Scholar]

9. Kyllonen PC, Christal RE. Reasoning ability Is (little more than) working-memory capacity? Intelligence. 1990;14:389-433. [Google Scholar]

10. Ricker TJ, AuBuchon AM, Cowan N. Working memory. Cogn Sci. 2010;1:573-585. [PubMed] [Google Scholar]

11. Petrides M. Lateral prefrontal cortex: architectonic and functional organization. Phil Trans R Soc B. 2005;360:781-795. [PMC free article] [PubMed] [Google Scholar]

12. Ballard IC, Murty VP, Carter RM, MacInnes JJ, Huettel SA, Adcock RA. Dorsolateral prefrontal cortex drives mesolimbic dopaminergic regions to initiate motivated behavior. J Neurosci. 2011;31(28):1034010346. [PMC free article] [PubMed] [Google Scholar]

13. Cowan N. Multiple concurrent thoughts: The meaning and developmental neuropsychology of working memory. Dev Neuropsychol. 2010;35(5):447-474. [PMC free article] [PubMed] [Google Scholar]

14. Sweller J, van Merrienboer JJG, Paas F. Cognitive architecture and instructional design. Ed Psychol Rev. 1998;10(3):251-296. [Google Scholar]

15. Kalyuga S, Ayres P, Chandler P, Sweller J. The expertise reversal effect. Educ Psychol. 2003;38(1):23-31. [Google Scholar]

16. Kalyuga S. Expertise reversal effect and Its implications for learner-tailored instruction. Ed Psychol Rev. 2007;19(4):509-539. [Google Scholar]

17. D'Ardenne K, Eshel N, Luka J, Lenartowicz A, Nystrom LE, Cohen JD. Role of prefrontal cortex and the midbrain dopamine system in working memory updating. Proc Natl Acad Sci U S A. 2012;109(49):19900-19909. [PMC free article] [PubMed] [Google Scholar]

18. Badre D. Opening the gate to working memory. Proc Natl Acad Sci U S A. 2012;109(49):19878-19879. [PMC free article] [PubMed] [Google Scholar]

19. Kyndt E, Dochy F, Struyven K, Cascallar E. Looking at learning approaches from the angle of student profiles. Educ Psychol. 2012;32(4):493-513. [Google Scholar]

20. Binder JR, Desai RH. The neurobiology of semantic memory. Trends Cognit Sci. 2011;15(11):527-536. [PMC free article] [PubMed] [Google Scholar]

21. Khodor J, Halme DG, Walker GC. A hierarchical biology concept framework: a tool for course design. Cell Biol Educ. 2004;3(2):111-121. [PMC free article] [PubMed] [Google Scholar]

22. Bar M, Aminoff E, Mason M, Fenske M. The units of thought. Hippocampus. 2007;17:420-428. [PubMed] [Google Scholar]

23. Halford GS, Wilson WH, Phillips S. Relational knowledge: the foundation of higher cognition. Trends Cognit Sci. 2010;14(11):497-505. [PubMed] [Google Scholar]

24. Halford GS, Andrews G, Wilson WH, Phillips S. Computational models of relational processes in cognitive development. Cognit Dev. 2012;27(4):481-499. [Google Scholar]

25. Orgill M, Bodner G. Locks and keys: An analysis of biochemistry students use of analogies. Biochem Mol Biol Educ. 2007;35(4):244-254. [PubMed] [Google Scholar]

26. Patterson K, Nestor PJ, Rogers TT. Where do you know what you know? The representation of semantic knowledge in the human brain. Nat Rev Neurosci. 2007;8(12):976-987. [PubMed] [Google Scholar] 
27. Badre $\mathrm{D}$, Wagner $\mathrm{AD}$. Left ventrolateral prefrontal cortex and the cognitive control of memory. Neuropsychologia. 2007;45(13):2883-2901. [PubMed] [Google Scholar]

28. Bunge SA, Wendelken C, Badre D, Wagner AD. Analogical reasoning and prefrontal cortex: evidence for separable retrieval and integration mechanisms. Cerebr Cortex. 2005;15(3):239-249. [PubMed] [Google Scholar]

29. Green AE, Kraemer DJ, Fugelsang JA, Gray JR, Dunbar KN. Connecting long distance: semantic distance in analogical reasoning modulates frontopolar cortex activity. Cerebr Cortex. 2010;20(1):70-76. [PubMed] [Google Scholar]

30. Kroger S, Rutter B, Stark R, Windmann S, Hermann C, Abraham A. Using a shoe as a plant pot: neural correlates of passive conceptual expansion. Brain Res. 2012;1430:52-61. [PubMed] [Google Scholar]

31. Kroger JK, Nystrom LE, Cohen JD, Johnson-Laird PN. Distinct neural substrates for deductive and mathematical processing. Brain Res. 2008;1243:86-103. [PubMed] [Google Scholar]

32. Badre D. Cognitive control, hierarchy, and the rostro-caudal organization of the frontal lobes. Trends Cognit Sci. 2008;12(5):193-200. [PubMed] [Google Scholar]

33. Fleming SM, Weil RS, Nagy Z, Dolan RJ, Rees G. Relating introspective accuracy to individual differences in brain structure. Science. 2010;329(5998):1541-1543. [PMC free article] [PubMed] [Google Scholar]

34. Novak JD. Concept maps and Vee diagrams: two metacognitive tools to facilitate meaningful learning. Instr Sci. 1990;19:29-52. [Google Scholar]

35. Raichle ME, MacLeod AM, Snyder AZ, Powers WJ, Gusnard DA, Shulman GL. A default mode of brain function. Proc Natl Acad Sci U S A. 2001;98(2):676-682. [PMC free article] [PubMed] [Google Scholar]

36. Lieberman MD. Education and the social brain. Trends in Neuroscience and Education. 2012;1(1):3-9. [Google Scholar]

37. Kim H. A dual-subsystem model of the brain's default network: Self-referential processing, memory retrieval processes, and autobiographical memory retrieval. Neuro Image. 2012;61:966-977. [PubMed] [Google Scholar]

38. Smallwood J, Fishman DJ, Schooler JW. Counting the cost of an absent mind: Mind wandering as an underrecognized influence on educational performance. Psychonomic Bull Rev. 2007;14(2):230-236. [PubMed] [Google Scholar]

39. Mason MF, Norton MI, Van Horn JD, Wegner DM, Grafton ST, Macrae CN. Wandering minds: The default network and stimulus-independent thought. Science. 2007;315:393-395. [PMC free article] [PubMed] [Google Scholar]

40. Spreng RN, Stevens WD, Chamberlain JP, Gilmore AW, Schacter DL. Default network activity, coupled with the frontoparietal control network, supports goal-directed cognition. Neuro Image. 53(1):303-317. [PMC free article] [PubMed] [Google Scholar]

41. Sebastian C, Burnett S, Blakemore SJ. Development of the self-concept during adolescence. Trends Cognit Sci. 2008;12(11):441-446. [PubMed] [Google Scholar]

42. Timmermans B, Schilbach L, Pasquali A, Cleeremans A. Higher order thoughts in action: consciousness as an unconscious re-description process. Philos Trans R Soc Lond B Biol Sci. 2012;367(1594):1412-1423. [PMC free article] [PubMed] [Google Scholar]

43. Fletcher L, Carruthers P. Metacognition and reasoning. Philos Trans $\mathrm{R}$ Soc Lond B Biol Sci. 2012;367(1594):1366-1378. [PMC free article] [PubMed] [Google Scholar]

45. Fleming SM, Dolan RJ. The neural basis of metacognitive ability. Philos Trans R Soc Lond B Biol Sci. 2012;367(1594):1338-1349. [PMC free article] [PubMed] [Google Scholar]

46. Mayer RE. Rote versus meaningful learning. Theory Into Practice. 2002;41(4):226-232. [Google Scholar]

47. Miller TM, Geraci L. Unskilled but aware: reinterpreting overconfidence in low-performing students. J Exp Psychol Learn Mem Cogn. 2011;37(2):502-506. [PubMed] [Google Scholar]

48. Salden RJCM, Koedinger KR, Renkl A, Aleven V, McLaren BM. Accounting for beneficial effects of worked examples in tutored problem solving. Educ Psychol Rev. 2010;22(4):379-392. [Google Scholar]

49. Corbett AT, Anderson JR. Knowledge tracing: Modeling the acquisition of procedural knowledge. User Modeling and User-Adapted Interaction. 1995;4:253-278. [Google Scholar]

50. Koedinger KR, Aleven V. Exploring the assistance dilemma in experiments with cognitive tutors. Educ Psychol Rev. 2007;19(3):239-264. [Google Scholar] 